\title{
Calling out the nameless: CocoRosie's Posthuman sound world
}

\author{
Jake Johnson
}

Oklahoma City University

\begin{abstract}
"To engage with CocoRosie requires absolute suspension of disbelief," writes The Guardian. This has as much to do with their music as their appearance, for sisterly duo CocoRosie have embraced what they call a "posthuman kind of style" rooted in the dissolution of gender. In an effort to imagine a world beyond human constructions of gender, CocoRosie creates a sound world that reflects this aesthetic of a genderless futurity. Following Donna Haraway's notion of the posthuman occupying a "post-gender world" and Drew Daniel's contention that "all sound is queer," supposing sound can sound gendered or de-gendered centers the discussion of posthumanity around the production and reception of sound. This discussion of CocoRosie, then, offers music scholars a particularly apt discursive model for examining what a post-gender (and thus posthuman) sound world sounds like. CocoRosie's strange music, I contend, carries a transformative impulse and in turn sounds the undoing of gender itself.
\end{abstract}

\footnotetext{
"It is in large part according to the sounds people make

that we judge them sane or insane, male or female,

good, evil, trustworthy, depressive, marriageable, moribund, likely or unlikely to make war on us, little better than animals, inspired by God."
}

Anne Carson, "The Gender of Sound"

From Ovid's Metamorphoses to Kafka's Metamorphosis, and from Virginia Woolf's Orlando to the science fiction of Phillip K. Dick, literary minds have questioned what qualities are required for humans to be human and not something else. Tellingly, humanism remains at root in all of these considerations. Even after Ovid's character Actaeon is transformed into a deer by Diana, his human intellect remains unchanged-his physicality has only shifted. Actaeon clearly remembers the names of his dogs even as it is him they unknowingly chase, and he hears his own name called as his search party scours the forest. Ovid sees Actaeon as both deer and human; for some reason, Actaeon the person remains. This reticence to let go of humanity's centrality in Ovid's Metamorphoses and other stories like it suggests the larger fear of a posthuman world lies less with the transformation than with relinquishing the power of being human. 
To claim humanity today is to occupy an unsettled position. The line between human and machine has become increasingly blurred, and more and more the traditional human constructions of sociality come under scrutiny as debates flourish about how humans might live alongside human-like beings, and how the nature of humanity itself may change in the process. Scholars have teased out many visions of the posthuman, and all with productive conceptions, albeit often seemingly at odds with one another. For my purposes, two of these visions seem most compelling: First, Nietzsche, whose Übermensch refers not to a higher kind of man, but to a becoming or a process, and second, Donna Haraway's notion of a "cyborg" as a creature who occupies what she calls a "post-gender world" (Haraway, 1990, 150). Together then, my sense of the posthuman is a process of transformation whose outcome is a world in which human constructions of difference-most significantly gender-cease to exist.

I combine these perceptions of the posthuman to suggest that one way to look at posthumanism is as a process of de-gendering sound. As voice studies scholars have pointed out, vocal sound has long remained a central qualifier for being human. Even in science fiction, such as Philip K. Dick's 1959 novel Time Out of Joint, where the voice remains the only gendered feature among otherwise homogenous-looking teenagers of a dystopic future, to lose gender through voice would be to enter a realm beyond the human (apparently a step too far for even science fiction writers to take).

What I explore here is how a posthuman sound world has been imagined in the music of the sisterly duo CocoRosie, who refer to their musical personae as "a kind of post human style where gender rules don't apply in the same way necessarily," as "evidence that we're returning more and more to nature and becoming more part of the landscape" ("Gettin' Cosy with CocoRosie," 2010). CocoRosie draws our ears toward the posthuman by imagining their voices as being unhinged from gender. They use vocal techniques such as vocal fry, belting, and a raised larynx to create sounds that oscillate rapidly between those accepted as gendered and those that confound any clear gender context. These rapid oscillations in vocal quality, I suggest, result in an envisioned sound world rooted in a perverse optimism, one in which the cure for ecological and social disasters lies in the sonic annihilation of constructed identities, such as gender, that collectively render us human. And while gender can hardly be pinned down as the sole defining element of being human, for CocoRosie such is their project: to confuse the gendered soundscape in order to reinvent a humanity unburdened with the depravities of patriarchy and the anti-ecological stronghold it sustains.

\section{SELF AND SOUND}

In Honoré de Balzac's philosophical novel Séraphita, lovers Wilfrid and Minna are both in love with an androgynous angelic figure named Séraphita. In the final chapter, Wilfrid and Minna are present when Séraphita ascends into heaven and both are left to reflect on the mysteries and wonders of the vision of heaven just afforded them:

Wilfrid and Minna now understood some of the mysterious words of the being who on earth had appeared to them under the form which was intelligible to each-Séraphitus to one, Séraphita to the other-seeing that here all was homogeneous. Light gave birth to melody, and melody to light; colors were both light and melody; motion was number endowed by the Word; in short, everything was at once sonorous, diaphanous, and mobile; so that, everything existing in everything else, extension knew no limits, and the angels could traverse it everywhere to the utmost depths of the infinite (Balzac, 1899, 149).

Wilfrid and Minna later refer again to the congeneric relationship of music and color:

As they recalled the stupendous efforts of the greatest human minds, they discerned the principle of melody as they heard the songs of heaven which gave them all the sensations of color, perfume, and thought, and reminded them of the innumerable details of all the creations, as an earthly song can revive the slenderest memories of love (150).

Balzac's imagery brings to bare a discussion of a metaphysical space where androgyny is enveloped in sound, which encompasses all other sensations of the body, "so that, everything existing in everything else, extension knew no limits." This conceptual space, beyond gender, is built around a framework of sound. Indeed, we could say that in this space 
sound is the mediator of a de-gendered embodiment. As mediator, then, sound carries a potential power and agency not typically afforded outside of the supernatural realm. And, as once perceived agents of that sound-particularly in embodying the vocal production of sound through song-humans in Balzac's world find their power corruptible, even to the point of losing the privileged and determining position as arbiters of sound. In such a vision of sensual homogeneity, the singing voice is severed from the body, its purpose then unhindered in "remind[ing] them of the innumerable details of all the creations."

Balzac provocatively unites sound and nature in a conceptual space that is also de-gendered. The effect of such a scenario carries implications about the nature of sound as bodily produced, and how embodiment projects that sound as gendered. This scene brings to relief recent musicological discussions of voice, sound, and agency. Drew Daniel argues that "all sound is queer" and in this sense, all sound can be gendered and, consequently, de-gendered (Daniel, 2011). Nina Eidsheim is more explicit when she writes that the way we train our voices becomes a material essence of the vocal sound, that "vocalization leaves a physical imprint and impression not only on the listener but on the vocalizer herself or himself" (Eidsheim, 2015b, 129; 2015a). She also upends the presumption that sound is a stable identifier of a person's subjectivity when she suggests that it is the listener who plays a more crucial role in shaping what voices sound like-that is, the authorship of a particular sound may belong more to the sound's receiver than its producer. On the other hand, David Blake's concept of "musical motility" in indie music suggests there exists "the projection of the self-outward through sound into the recording." Blake borrows Merleau-Ponty's concept of motility and argues that sound, as projected into a recording, carries a certain agency and identity of its own which "question[s] the existence of 'the music itself." He asks, "If musical motility projects the self into sound, what is that self, and how can it be perceived by listeners and described by analysts?" (Blake, 2012).

As Daniel and Blake propose, if sound can carry its own identity, then how that sound acts upon listeners can also enact an aural association between that sound and the identity it projects. Alternatively, Eidsheim would have us consider how the listener acts upon that sound, assigning both a sonic and social identity to what they hear. All three scholars have differing explanations for how a sound's identity gets framed. Yet one point of unity among them is that their work points toward an experience of sound that is at odds with previous assumptions about the agency of sound and from where its identity (if any) comes. This tension between sound agency and human agency, between the producer of sounds and the hearer of sounds, highlights the assumptions humans make about their centrality in the known sound world. The provocative question of whether or not a tree falling in the woods makes a sound if no human is around to hear it gets exactly to the heart of the privileged place we assume human hearing to occupy. For our purposes, these tensions are productive: such an ontological freshness is needed both to flesh out the construction of gendered and degendered sounds as well as to provide a discursive model for what a post-gender (and posthuman) world sounds like. This is all the more pressing when considering the music of sisterly duo CocoRosie, whose strange sounds, I contend, carry a transformative impulse and in turn sound the undoing of gender itself.

More to the point, however, is that the human voice is at root the tool needed to access such a post-human sensibility. Judith Peraino sets up a discussion about the role the voice might play in decentering gender when she asks three powerful questions: "Must the singing voice play by the same rules as the speaking voice? Must it bear the indelible mark of a binary gender system? Could the singing voice perhaps offer an escape from that system?" Peraino connects these questions to her example of oscillations between the normal speaking voice and the falsetto singing of androgynous performer Sylvester as a signifier of gender and its undoing.

The 'femininity' of the singing voice calls into question the 'masculinity' of the speaking voice, and in turn the 'masculinity' of the speaking voice calls into question the 'femininity' of the singing voice... Sylvester used his singing voice, then, to confound the gender binary from either pole ... that is, his vocal breaks sound the moments when gender itself breaks down, when expectations of an alignment between voice and gender are thwarted, and we begin to wonder whether the categories 'male' and 'female' can even be applied (Peraino, 2007, 62).

In other words, Sylvester's voice produced so unnatural a shift in sound quality as to "confound the gender binary" and de-gender the conceptual space surrounding that sound production. Shana Goldin-Perschbacher comes to a similar conclusion about Jeff Buckley's singing, which results in what she calls "transgenderd vocality-a vocality that 
resists identification with ... biological sex" (Goldin-Perschbacher, 2007, 215). It is through singing, Peraino and GoldinPerschbacher argue, that performers like Sylvester and Buckley are able to move into a post-gender realm, much like in the scene from Séraphita described above. Such a "posthuman" space, I contend, offers a manner of approaching de-gendered sound analytically and develops an aperture through which scholars may gain access to a post-gendered sound world.

\section{I CEASING TO BE HUMAN}

In his Introduction to the Reading of Hegel, Alexandre Kojeve situates Hegel's perception that "At the end of history man disappears" though "the natural World remains what it has been from all eternity.... Man remains alive as animal in harmony with Nature as another Being. What disappears is Man properly so-called" (Kojeve, 1980, 158). From Hegel's view, humans eventually dissolve into the landscape of nature. They thereby are not annihilated in "cosmic catastrophe" but become transformed into something more harmonious and animal-like. This resonates with what Deleuze and Guattari would later call the "becoming-animal"-a creature capable of "traversing human beings and sweeping them away, affecting the animal no less than the human" (Deleuze \& Guattari, 1987, 237). Such a transformation from human to becoming-animal involves loss of the stabilizing dynamics of identity-"from unity to complexity ... from organization to anarchy." The world of the becoming-animal, then, is one of "pure intensities, where all forms come undone, as do all the significations, signifiers, and signifieds" (Deleuze \& Guattari, 1986, 13).

There are, of course, many literary examples of what could be called a becoming-animal, as I implied in the opening paragraphs. The consequences of such a process, though, are much more harried and pronounced than what Deleuze and Guattari describe. To press Ovid's image a little further, the story of Actaeon brings into focus an unsettling vision of what it can mean for a human to cease to be human yet still retain human consciousness. When she discovers him watching her in the woods while she bathed, the goddess Diana furiously transforms Actaeon into a deer. When his own dogs begin chasing him, unknowing him in his transformed state, and he hears in the distance his friends searching for him and calling him by name, Actaeon "turned his head at the sound of his name." "Well might he wish to be absent," Ovid writes, "but he was all too surely present" (Ovid, 1955, 79). Like Actaeon, Gregor Samsa in Kafka's story of another metamorphosis is most distressed by his intact consciousness though his body has transformed into that of a bug. In Orlando, Virginia Woolf puts a gendered spin on the metamorphosed myth whenever her title character awakens a woman though he previously was a man, yet consciousness remained unaffected: "Orlando remained precisely as he had been. The change of sex, though it altered their future, did nothing whatever to alter their identity" (Woolf, 1928 [2006], 102-103).

Part of Actaeon's anguish is that he retains human hearing but loses the ability to speak as a human, since he "turn[s] his head" to the sound of his name but cannot in any way respond "it is I!" In fact, being able to hear his voice is one way Ovid explains how Actaeon the person is still "present" in Actaeon the animal. Similarly, we might well imagine that the male version of Orlando and the female version of Orlando have distinctly different sound qualities, as per fitting the physiology of the human voice, so that Orlando's gender transformation, like Actaeon's, also enacts an erasure of a previous sound world. This particular terror of transformation-the loss or transmutation of one's voice while hearing, memory, and consciousness are kept intact-challenges perceptions of what it means to be human and brings to bare how sound and voice figure into that identity. "Ceasing to be human," writes Gerald Bruns, "means losing one's voice, that is, losing one's capacity for being recognized as human." He goes on to question the consequences for such a transformation.

Of course Ovid's story is about the failure of recognition, or of reidentitification, but one wonders, what would the story have been like had Actaeon's friends been able to recognize him, changes and all? What would their experience have been like? How [to] respond to someone who is no longer (visibly) human but not, or not yet, wholly otherwise? (Bruns, 2011, 32). 
Human myths are replete with characters who fit Bruns's description of not human but also not something else either. Werewolves, vampires, monsters like Shelley's-born from the ills of man's tampering with technology-and, most current, zombies or the undead all fill the imagination with scenes of panic or mayhem instigated by those neither human nor otherwise. Science fiction similarly fashions worlds in which humans co-exist with intelligent machines that often look humanoid. The greatest source of anxiety in such stories rests upon the inability for listeners to distinguish human sounds from those designed to sound like humans. Stanley Cavell argues that such is the nature of existence, where sense perception fails to distinguish what is human and what is not.

Obviously you can never be certain that other human beings exist, for any one you single out may, for all you know, be something other than you imagine, perhaps a human, probably a human if you like, but possibly a mutation, and just possibly an automaton, a zombie ... The world is what it is. And whatever it is, so far as you take it as inhabited by candidates for the human, you are emphatically projecting. This means that you cannot rule out the non-human (or human non-being) possibility (Cavell, 1999, 423-424).

The anxiety of not being able to trust perception in identifying something as human or not has increased manifold today. Virtual voices and digitized human likenesses-from Japanese holographic sensation Hatsune Miku to Siri's human-like voice-are a part of the human soundscape to such a degree now that the vying for "human" can seem a crowded room. As non-human machines become more facile at sounding like humans, then listeners must become more disciplined in their hearing. The urge to uncover the origins of man, then, is a very human-like response for those unsure of how humans and the non-humans will occupy this crowded space.

Essential to this asking, though, is a determination of what it means to become human in the first place. Foucault and Sartre both agree that the human self does not exist unless or until carved out through purpose. "Man is nothing else but what he purposes," claims Sartre, "he exists only insofar as he realizes himself, he is therefore nothing else but the sum of his actions, nothing else but what his life is" (Sartre, 1959, 300). Foucault, in speaking of Baudelaire, suggests not just realization, but an even greater action or invention is needed in order to become human: "Modern man, for Baudelaire, is not the man who goes off to discover himself, his secrets and his hidden truth; he is the man who tries to invent himself. This modernity does not 'liberate man in his own being'; it compels him to face the task of producing himself" (Foucault, 1997, 312). Like Cavell's notion that humanness "is not a given; it has to be created" (Bruns, 2011, 18), Foucault also favored a conception of the human framed in creation. "From the idea that the self is not given to us, I think that there is only one practical consequence," he claimed. "We have to create ourselves as a work of art" (Foucault, 1997, 262). If this artistic intellectuality, or formalistic approach to becoming human, seems strangely unhuman, Cavell urges us to consider precisely how philosophy, as "a drive to the inhuman" is "somehow itself the most inescapably human of motivations" (Cavell, 1989, 50).

\section{3 | A SUSPENSION OF DISBELIEF}

"To engage with CocoRosie requires absolute suspension of disbelief," wrote Maddy Costa of The Guardian (Costa, 2010). Indeed, sisters Bianca and Sierra Casady have provoked audiences since their DIY-inspired debut album La Maison de mon reve in 2003, which they recorded in Sierra's Parisian bathroom. One thing that makes CocoRosie's music so distinct is their collection of instruments, however loose that description might be. Using a small cadre of children's plastic toys and prerecorded sounds frequently taken of barnyard animals, the Casady sisters fill their music with a strange and creepy collection of disembodied sound memories that at once complement and work in contrast with their distinct voices. Sierra, who studied opera performance while living in Paris, frequently sings with a heavy vibrato and affected vocal quality expected given the kind of training she received. Bianca, on the other hand, frequently manipulates her voice to sound like a creepy mixture of Bjork and Billie Holiday. Paired together, the human voices of CocoRosie actually lack a definitive humanness, which, after all, is their stated intention. Rather, it is the regular intrusion of the sounds from children's toys into the mix that strangely humanizes the otherworldly vocality the sisters produce. ${ }^{1}$ 
If listening to CocoRosie is disorienting, the way the sisters present themselves is equally alarming. Both sisters regularly give incoherent or wandering interviews, often digressing into earnest salutations on the end of the world. In these interviews, the sisters rarely appear without hand-drawn facial hair or smeared makeup covering their otherwise attractive faces. For many years, they also hand-fashioned clothes to match the atmosphere of the poem "Wee Willie Winkie" because of their admiration for the "protector of children" they saw in the poem's title character.

All together, the Casadys project a gothic aural and visual demeanor that might be expected from the imagination of a science fiction writer. Indeed, the degree to which the sisters pursue a complete self-effacement seems eerily similar to the dystopian vision Kurt Vonnegut imagines in his 1961 short story "Harrison Bergeron." Vonnegut's story highlights the retributive nature of equality, as those with innate abilities or characteristics of excellence that would otherwise set them apart are "handicapped" in order to preserve some facade of equality. The thin line separating the desire for equality and the drive for retribution is thus brought to the fore in "Harrison Bergeron." Ballerinas must dance wearing heavy chains, athletes must perform their work while shackled, natural beauty must be masked, and intellectuals are assigned earpieces that irregularly blast loud streams of radio interference in order to inhibit their innate cognitive abilities.

The Casady sisters' penchant for misleading audiences through "handicapping" by donning aural and visual identity masks could be interpreted as a similar act of erasure, destabilizing the landscape of visual and aural perception. Not all critics of CocoRosie are so convinced. As Costa writes, "The more you look at CocoRosie on stage, the more contrived they seem," adding that "the wizardry starts to look a sham" (Costa, 2010). This could be a radical stunt for publicity; pop stars are rarely prized for their sincerity, and precedents for similar types of behavior are not difficult to muster. One only has to think of Garth Brooks's garbled and startling digression into his alter ego Chris Gaines to draw a parallel to radical personas of the recent past.

Yet, I think there is something oddly sincere about CocoRosie. It is this implied sincerity intermixing with the obvious irony-what Sierra calls a "deliberate mistranslation" - that is so intriguing (Eberstadt, 2008). Scholars working through the concept of metamodernism have suggested musical groups like CocoRosie are embracing a New Romanticism that builds from the writings of Schiller and Novalis. For examples, the frequent themes of nature, the loss of childhood, and mythological creatures pervade the work of CocoRosie and other "freak folk" artists. "The world must be authentic again in a way nature, the child's imagination, and ancient folk music are regarded or constructed as being authentic," writes one scholar (van Poecke, 2014).

Timotheus Vermeulen and Robin van den Akker sum up the sincere irony manifest in those reflecting a New Romanticist aesthetic.

The category of the everyday has been central to both the modern and the postmodern. Modernity can be characterized by an anxiety to reconstruct the everyday in the name of this or that universalism. Postmodernity can be described as the neurosis to deconstruct it along the heterogeneous lines of race, gender, and place. New Romanticism attempts to both-neither reconstruct and-nor deconstruct the commonplace. It seeks to come to terms with the commonplace as it is while at the same time imagining how it could be but never will be. It presents us with the impossible possibility of another here-and-now.

But why now? Why have artists taken to these Romantic sentiments all of a sudden? Our answer is that Romanticism provides them with the vocabulary and iconography to express a dissatisfaction about a present that is increasingly uninhabitable, and a desire for a future whose blueprint has yet to be drawn. New Romanticism expresses the transition from a place not yet left behind, to another space it has not yet entered, and probably never will. Ominous ruins as symbols for the cliffs of the past. Mysterious sects in situ the shores of the future ("New Romanticism," 2010).

The "impossible possibility of another here-and-now" elevates CocoRosie's projection of a New Romanticism onto a much larger trend in a world no longer recognizable as post-modern. Rather, the impossible possibilities point to the rapid oscillations between the sincerity of modernism and the irony of postmodernism, out of which surfaces the sensibility known as metamodernism. If CocoRosie, to quote Novalis, feels that "the world must be romanticized" to "yield again its original meaning," it is only because the current world is uninhabitable and far less approachable than 
the one they are constructing (Novalis, 2007, xvi). If the human world deserves to be saved, the Casady sisters believe it must be estranged-confused in order to be understood clearly. ${ }^{2}$

Raised by an apparent abusive father infatuated with Native American lore and their mother a Waldorf teacher and disciple of Rudolf Steiner's mysticism, the Casady sisters discerned an association between their cryptic childhood and the natural world around them. The resulting sonic and visual imagery CocoRosie captures in their music suggests there can be a mystical and natural salvation from human foibles. For example, Sierra Casady frequently plays the harp, counterbalancing its acoustic and signification qualities as "folk" with beat boxing or prerecorded material. This simultaneously distances the authentic folk sounds from modern technology while also uniting them in an ironic position intent on discomfiting listeners who may wonder from which ideology they are meant to hear authenticity: traditional or technological sounds. From sounding like a child to using children's toys as instruments, and even to their name itself-the duo's name an amalgamation of their mother's childhood names for each girl-CocoRosie invigorates childhood's precocious qualities while at the same time elevating its innocence into a serious discussion on the future of humanity. It is within this framework that I offer in these final pages a textual and musical analysis of how embodying one of CocoRosie's musical personas, the young Grass Widow, reflects the sisters' tampering with a posthuman sensibility.

\section{4 | CALLING OUT THE NAMELESS}

For their 2013 album Tales of $a$ Grass Widow, CocoRosie worked alongside British singer and artist Antony Hegarty (also known as Anohni) on several tracks. Referring to Hegarty as their "grandmother," the Casady sisters found in Hegarty a staunch supporter and loyal friend early in their career. Part of their appeal to Hegarty, and her featuring in their music, is her identity as transgender. Bianca Casady, who identifies as gay "no matter what relationship I am in," has mentioned the sisters' adoration for the concept of "tranny" as encompassing a broader ideological framework their music is built around. Citing "tranny" as a "transition between lifetimes, states, elements-between a lot of thingsreally embracing this idea of being in constant transition," Bianca makes a claim for the transitive power of identifying as transgender, one that positions someone like Hegarty in a world where normative gender ideals are obfuscated, a world they decidedly seek for their own.

The liminality of the "tranny" offers the sisters an in-but-not-of-the-world position from which to construct their vision of the posthuman, yet their arrival at that term seems haphazard. Indeed, the idea of transgendered inbetweenness is more helpful for their project than any meaningful engagement with how or what it means to occupy that liminal space as a "tranny." Indeed, CocoRosie's adoption of the term can be unsettling, particularly since the nontransgendered sisters seem only interested in claiming the alterity or queerness of being a transgender person without the political or social repercussions that have come with that identity. In some uncomfortable ways, CocoRosie's romanticizing of transgender as "being in constant transition" smacks of opportunism at best, and at worst the undiscerning adoption of queered personas by cisgender persons that Drew Daniel calls "queer minstrelsy" (Daniel, 2013).

Nonetheless, CocoRosie claims a transgender space to reiterate the slippery concepts of two gender identities and then uses that conceptual space to construct both sonic and bodily representations of gender alterity. "Gender is becoming really ambiguous," Bianca told The New Gay TV. "Things are breaking down recently, I feel like." Whenever asked why they wear goatees, Bianca said,

We started to fashion ourselves after elemental beings, fairies and gnomes, kind of a posthuman style where gender rules don't apply in the same way necessarily, where facial hair isn't particularly explanatory of one's gender. It's more of an adornment or evidence that we're returning more and more to nature and becoming more part of the landscape ("Gettin' Cosy with CocoRosie," 2010).

This dissolution into the landscape brings back to mind Hegel's description of the end of humans not as the result of an external, cosmic catastrophe, but rather of an internal nature-one in which humans recede from sight by their own volition and become like other animals. 
In the song "Tears for Animals," Antony Hegarty frequently sounds the cry "Do you have love for humankind?" Hegarty's question if listeners have love for humankind demands a simple response but, because of the context established by the song's title, a simple response cannot be given. Singing of rape and abuse, heartbreak, and orphaned children give sound to all too familiar human problems. It is unclear, however, if these stories are told from one human to another or, as the title suggests, if they come from an animal's perspective or are otherwise directed from a human to a non-human. Confusing the emotional response to human suffering presented in the text by the choice of title unsettles the listener, forcing us to reframe our understanding of where our love for humankind is rooted and-even more pressing-if what we think we are loving turns out not to be humankind after all.

Throughout the album, Bianca Casady dons the persona of her character "the Grass Widow." She creates an unreal sound for the Grass Widow by manipulating her voice-oscillating rapidly between singing with a raised larynx (which produces a Kermit the Frog type color) and singing on a vocal fry, which involves physically relaxing the vocal cords to where sounds pop or fizzle out. Rapidly shifting between extreme sounds allows Bianca to capitalize on a form of genderless sound construction, particularly in the song "Child Bride," and reflect the metamodern sensibility described earlier. The result is an otherworldly, childlike voice that resists easy categorization precisely because the voice is so unsteady; it slips in and out of the listener's gendered framework for identifying sounds.

As Bianca sings about the young Grass Widow cleaning her body in preparation for her new role as a bride ("It is hard to tell/Whose little girl am I./The man with the black hat/Will take me home tonight./I wash my body, five years grown"), she suddenly shifts out of the mid-range, standard pop tessitura and up a minor seventh to the B-flat on the word "body," which she belts. Compare this sound with every other instance of that same interval in the rest of the song, in which Bianca quietly approaches the leap, even backing away from the upper pitch in somewhat of a whisper, and the belt in this moment seems to be accomplishing more than just eliciting an emotional response, but is drawing attention to sound more overtly. Indeed, Bianca's unaffected voice emerges out of the texture in this instance, dropping momentarily the sonic character of the Grass Widow by belting, using discriminately a vocal quality that many voice practitioners have come to describe as more "authentic or truthful" than other styles of singing (Ragsdale, 2004, 46).

Bianca's treatment of the sound quality here is significant, both to the story but also to CocoRosie's overall perception of a posthuman sound. The clear and strong belt sounds considerably out of place, and out of character, from the frail, child-like, and powerless voice she uses throughout most of the song. Belting, on the other hand, is intended to sound powerful-so powerful, in fact, that it can damage the voice, as many pop and Broadway singers can attest. Its use, however, is vital for the female voice to be heard over the increasingly encroaching sounds of the band or pit orchestra. Furthermore, as Carolyn Abbate has pointed out with women in opera, there is a symbolism attached to the power of women singing on stage with a social power of resistance (Abbate, 1993).

These perceptions of vocal power are shattered in "Child Bride." Bianca's turn to the belt sound as the young Grass Widow considers the appropriateness of her soon to be sexualized body could be read as a shift away from the vapid sounds of a woman imitating a child's voice to the most powerful vocalization women can produce. Yet Bianca does not afford this powerful belt to the rest of the song; rather, there is an aural diffusion. The oscillation between the two sounds actually problematizes the concept of gendered vocality. This quick oscillation, like the shift between modernist sincerity and postmodernist irony, gives the voice an uncanny affect. It's as if Bianca is taking both the powerlessness of child-speak and the powerful sounds of belting and turning them on their heads, probing the listener to adapt to a sound world where typical gender constructions are no longer dependable, and the power that once characterized them now diffuse.

The instrumentation also introduces a character closer to home for the Casadys. What sounds like a Native American flute hovers throughout the song. The turn to primitivism here calls to mind Marianna Torgovnick's observation on the role of primitivism in defining the present-in this context intriguingly couched within a metaphor of vocality: "The primitive does what we ask it to do. Voiceless, it lets us speak for it. It is our ventriloquist's dummy-or so we like to think" (Torgovnick, 1990, 9). Thus gesturing toward the primitive gives CocoRosie yet another means of identifying with a position of alterity, similar to their exploitation of the term "tranny." The nod to primitivism also functions as an 
autobiographical fission between the Grass Widow's father and the Casady sisters' own shamanist father. The Grass Widow's father abandons her to the will of another man, consequently foreclosing the Grass Widow's innocence. In turn, the Grass Widow looks to nature for solidarity, evoking the longstanding association between the feminine and nature: "News from the sparrow/my friendly fellow" tells her that her father and mother "get along just fine without me/They are never lonely." The Grass Widow finds relief in the natural world, not unlike countless fairy tales such as Cinderella, where a disfavored and abandoned young girl finds friendship in woodland creatures around her. Bianca and Sierra often place their songs within pastoral settings too, but their frequent allusion to an abusive and damaging upbringing at the hands of their father unites them in this narrative of patriarchal violence. The sisters feature what sounds like a Native American flute, an instrument likely associated with the Casady sisters' father, as if to claim the Grass Widow's story as their own, albeit in a more figurative manner.

The character of the Grass Widow weaves throughout CocoRosie's albums, as do other characters. Sierra's vocal treatment in "Child Bride" functions as atmospheric, but primarily as an anachronistic narrative device. Entering upon the Grass Widow's acceptance of her lonely fate, we hear Sierra's hallowing cries of despair in the distance as she wails in a descending motive repeated several times. Sierra's wailing voice haunts the story of the Grass Widow in "Child Bride," but also returns in other songs as well. In the song "Gravediggress," the Grass Widow asks an old woman to "dig me a hole I can bury/All of my love and all of my holy." Bianca, singing still in the affected childlike voice, performs the role of the Grass Widow while Sierra portrays the old woman. When we last left the Grass Widow, she had accepted her fate in "Child Bride" and now, bereaved of her mother, asks this strange woman to dig her a grave for her lost innocence. This is consistent with what Sierra stated in an interview: the Grass Widow is "not a widow mourning the loss of a husband, but a child that's mourning the loss of innocence" (Gupta, 2013).

The innocence the young Grass Widow buried in "Gravediggress" makes room for "the blue-eyed devil" who is "buried deep" in the song "We Are On Fire." As the chorus resounds with "I used to have eyes the color of sky/Now I can see in the middle of the night," listeners are introduced to a creature who is no longer who she once was. The animal references are significant. Transforming into an animal that is neither one thing nor entirely another-the big black dog with the soul of a cat-has literally given the Grass Widow a new pair of eyes, a new way to see the world. Musically, the two sisters are finally aligned in this track, whereas the other two songs have featured them in conversation, if not in contrast, with one another. This suggests also a conflation of young and old soundscapes into a different one, not entirely old and not entirely new either. The reason for this conflation, we learn in the final verse, is because the Grass Widow is no longer living. It could be that the older voice was her own voice all along, but a twisted and damaged one, now having lost her innocence, contemplating-perhaps even comforting-memories of the abuses the young Grass Widow faced. "Twas a deadly nightshade which finished me" suggests the Grass Widow's suicide by way of ingesting the toxic berries, and subsequent haunting of "the old church yard and the damn dog pound" ushered in her metamorphosis.

We might interpret this as all symbolic, of course. The Grass Widow used nature's toxins as a release from her gendered position, calling into question at once both nature's and the Grass Widow's associations with the feminine. Afterward, she becomes unrecognizable-"Nows I'm humbug and I'm harlot/Harmless monster with flowers in your hair." Yet, as the lyrics attest in "Harmless Monster," this estrangement is to be embraced, not feared. A musical transformation occurs as the final line, "It's all right to recognize me/Call out my nameless," is repeated six times. The timidity of Bianca's voice, stymied by what sounds like chokes of emotion, gives way to a powerful anthem as Sierra later joins in harmony. Again, the combination of the character's voices underscores the notion of being not one thing, but also not entirely another. The sisters seem to be encouraging an acceptance of this new identity, one forged through a loss of innocence. Yet that power is recouped when, like that of the tranny, the liminal space between constructions of identity becomes a platform of activism. It is here that CocoRosie's vision of a transformed humanity is given the most immediacy: the "nameless" of their "harmless monster" represents a creature inhabiting a world beyond gender and, thus, beyond inevitable gendered deprivations. To call out the nameless is to voice what yet does not exist, to grant this unknown creature the dignity of a name that sounds like nothing humans have ever heard before. 


\section{5 | CONCLUSION}

CocoRosie's sound world forces us to reconsider the implications of being human, of what totalizing force we bring to bare against the environment, other creatures, and one another, and the active role of the listener in framing much of our reality. Yet what are the implications of the posthuman sound world that CocoRosie attempts to create? What can understanding sound as existing beyond gender accomplish in terms of our lived experiences of gender? It seems that, no matter the strange sounds CocoRosie may try to produce in order to keep listeners from placing their voices within a gendered framework, much of the burden of creating a de-gendered or posthuman sound world rests with CocoRosie's listeners, not themselves. "Sound is never about the relationship between things," Salome Voegelin reminds us, "but is the relationship heard" (Voegelin, 2010,49). Indeed, it is the disciplining of the ear-not the manipulation of the voicethat will finally dislodge gender from the sounds people make. As it stands now, however, Nina Eidsheim's insistence that we need to take ownership of-and perhaps be held responsible for-how we identify sounds is a proscriptive rather than descriptive position for most listeners. Indeed, Anne Carson's observation cited in the epigraph still remains accurate: for better or worse, we judge people based on the sounds that they make. Categorizing humans based on the way they make sound will likely continue to be the norm if the power of listening is not persistently taught.

Perhaps the most radical aspect of CocoRosie's vision of the posthuman is that, at some point in the future, human ears may indeed become deaf to gender or other measures of social identity, and unjust categorizations of people eventually grow silent. Their vision recalls Hegel's, where humans cease to exist because they have chosen a higher pathone he describes as being harmonious. Singing therefore grants the person listening at the edge of humanity an opportunity to hear in the singing voice qualities of the posthuman. In truth, drawing attention to the essence of voice-the ineffable quality that is left when speech is stripped of logos-leads us into a posthuman rationality that, as Adriana Cavarero admits, is something "disturbingly close to animality" (Cavarero, 2005, 34). What is lost in Hegel's vision of the end of humanity then may be of less concern than what is gained. It is in this vision that the un-becoming of humanity will finally usher in relief from ourselves, for the turn away from humanity may indeed depend on our deafness to the sensation of difference-so much so, that what makes us human in the first place dissolves forever from the landscape itself.

\section{NOTES}

${ }^{1}$ Some have suggested that, with CocoRosie, we are dealing with a post-Bjork gendered sound. Although both CocoRosie and Bjork exhibit a sense of the posthuman in their vocals, much of the scholarly treatment of Bjork's posthumanism follows Haraway more explicitly, focusing on dualities between nature and technology, for example. The nature/technology binary is present in CocoRosie's music as well, of course, but I see this in itself more as an extension of New Romanticism's penchant for oscillation than posthumanism per se. See, for example, Chia Godfree (2005) and Andrew Robbie (2007).

${ }^{2}$ Admittedly, this position is one of privilege, and something scholars of the metamodern have not satisfactorily addressed. To make oneself appear unattractive is to have been attractive in the first place; to achieve purposeful incoherence in interviews requires cleverness and intellectual stamina; even the act of questioning societal values implies a relatively powerful position from which to voice these concerns, let alone argue for those values' total disintegration. Metamodernism may have an activist bent, but it seems ordained to be practiced largely from the position of comfort.

\section{WORKS CITED}

Abbate, C. (1993). Opera, or the envoicing of women. In R. A. Solie (Ed.), Musicology and difference: gender and sexuality in music scholarship (pp. 225-258). Berkeley: University of California Press.

de Balzac, H. (1899). Séraphita: a daughter of eve, and other stories. Translated by C. Bell \& R. S. Scott. Philadelphia: Gebbie Publishing Co.

Blake, D. K. (2012). Timbre as differentiation in Indie Music. Music Theory Online, 18.

Bruns, G. (2011). On ceasing to be human. Stanford: Stanford University Press.

Cavarero, A. (2005). For more than one voice: toward a philosophy of vocal expression. Translated and with an introduction by P. A. Kottman. Stanford: Stanford University Press. 
Cavell, S. (1999). The claim of reason: Wittgenstein, skepticism, morality, and tragedy. New York: Oxford University Press.

Cavell, S. (1989). An interview with Stanley Cavell. In R. Fleming \& M. Payne (Eds.), The senses of Stanley Cavell. Lewisburg, PA: Bucknell University Press.

Costa, M. (2010). CocoRosie. The Guardian. Retrieved from http://www.theguardian.com/music/2010/may/06/cocorosiereview

Daniel, D. (2011). All sound is Queer. The Wire (333).

Daniel, D. (2013). 'Why be something that you're not?': Punk performance and the epistemology of queer minstrelsy. Social Text, 31(3), 13-34.

Deleuze, G., \& Guattari, F. (1986). Kafka: toward a minor literature. Translated by D. Polan. Minneapolis: University of Minnesota Press.

Deleuze, G., \& Guattari, F. (1987). A thousand plateaus. Translated by B. Massumi. Minneapolis: University of Minnesota Press.

Eberstadt, F. (2008). Twisted Sisters. New York Times. Retrieved from http://www.nytimes.com/2008/07/06/magazine/ 06cocorosie-t.html

Eidsheim, N. (2015a). Race and the aesthetics of vocal timbre. In O. Bloechl, M. Lowe \& J. Kallberg (Eds.), Rethinking difference in music scholarship (pp. 338-365). Cambridge: Cambridge University Press.

Eidsheim, N. (2015b). Sensing sound: singing and listening as vibrational practice. Durham: Duke University Press.

Foucault, M. (1997). What is enlightenment? In J. D. Faubion (Ed.), Essential works of Foucault: 1954-1984 (Vol. 1). Translated by R. Hurley et al. New York: New Press.

"Gettin' Cosy with CocoRosie. (2010). The New Gay TV. Retrieved from https://www.youtube.com/watch?v=YnhUuYqNzzA

Godfree, C. (2005). Breaking down binaries: redefining gender and sexuality through the music videos of Bjork and Missy Elliott. Spectator, 25, 61-70.

Goldin-Perschbacher, S. (2007). 'Not with you but of you': 'unbearable intimacy' and Jeff Buckley's transgendered vocality. In F. Jarman-Ivens (Ed.), Oh boy! Masculinities and popular music (pp. 213-233). New York: Routledge.

Gupta, N. (2013). CocoRosie brings musical beauty to Boston. Melisma Magazine. Retrieved from http://sites.tufts.edu/ melismamagazine/2013/10/15/cocorosie-brings-musical-beauty-to-boston/

Haraway, D. (1990). Simians, cyborgs, and women: the reinvention of nature. New York: Routledge.

Kojeve, A. (1980). Introduction to the Reading of Hegel: lectures on the phenomenology of spirit. Ithaca: Cornell University Press.

"New Romanticism. (2010). Notes on Metamodernism. Metamodernism.com. Retrieved from http://www.metamodernism. com/2010/08/09/new-romanticism/

Novalis. (2007). Notes for a romantic encyclopaedia: Das Allgemeine Brouillon. Translated and edited by D. W. Wood. Albany: State University of New York Press.

Ovid. (1955). Metamorphoses. Translated by M. M. Innes. London: Penguin Books.

Peraino, J. (2007). Listening to gender: a response to Judith Halberstam. Women and Music: A Journal of Gender and Culture, 11, 59-64.

van Poecke, N. (2010). The new weird generation (I). Notes on Metamodernism. Metamodernism.com. Retrieved from http://www.metamodernism.com/2010/09/08/the-new-weird-generation-part-1/

Ragsdale, F. (2004). Perspectives on belting and belting pedagogy: a comparison of teachers of classical voice students, teachers of nonclassical voice students, and music theatre singers. PhD Dissertation, University of Miami.

Robbie, A. (2007). Sampling Haraway, Hunting Bjork: Locating a Cyborg Subjectivity. Repercussions, 10, 57-95.

Sartre, J. (1959). Existentialism is a Humanism. In W. Kaufmann (Ed.), Existentialism from Dostoevsky to Sartre. New York: Meridian Books.

Torgovnick, M. (1990). Gone primitive: savage intellects, modern lives. Chicago: University of Chicago Press.

Voegelin, S. (2010). Listening to noise and silence: towards a philosophy of sound art. New York: The Continuum International Publishing Group.

Woolf, V. (1928 [2006]). Orlando: a biography. New York: Harcourt.

How to cite this article: Johnson J. Calling out the nameless: CocoRosie's Posthuman sound world. J Pop Music Stud. 2017;00:e12223. https://doi.org/10.1111/.jpms.12223 


\section{Queries}

Q1: Author: Please confirm that given names (red) and surnames/family names (green) have been identified correctly.

Q2: Author: Reference "van Poecke, 2014" is not listed in the reference list. Please provide complete bibliographic details for the same.

Q3: Author: Please update reference "Daniel (2011)."

Q4: Author: Reference "van Poecke (2010)" is not cited in the text. Please provide citation. 